\title{
The polycyclic tectonic and
} petrogenetic evolution of the Juiz de Fora Complex: Constraints from zircon studies (U-Pb and Lu-Hf) coupled with whole-rock geochemical and (Sr-Nd) isotopic data

LUCAS EDUARDO DE ABREU BARBOSA ARAUJO ${ }^{1}$, MONICA HEILBRON ${ }^{1}$ AND WILSON TEIXEIRA ${ }^{2}$

${ }^{1}$ Rio de Janeiro State University

${ }^{2}$ Institute of Geosciences, University of São Paulo

Presenting Author: lucaseduardo9393@gmail.com

The Juiz de Fora Complex (JFC) is one of the Paleoproterozoic basement units affected by Neoproterozoic Brasilian/Pan-African orogenesis in the Central Ribeira Belt, southeastern Gondwana (SE Brazil) ${ }^{[1]}$. The JFC has a polycyclic character, comprising deformed orthogranulites which present a large range in ages and geochemical compositions of their magmatic protoliths ${ }^{[2]}$. In order to constrain preliminary petrogenetic aspects of its magmatic episodes and the tectonic evolution of the JFC throughout the Paleoproterozoic, we chose 6 rocks that each present distinct whole-rock geochemical and $\mathrm{Nd}-\mathrm{Sr}$ isotopic signatures to be analyzed by in-situ $\mathrm{U}-\mathrm{Pb}$ (SHRIMP and LA-MC-ICPMS) zircon geochronology and LuHf (LA-MC-ICPMS) isotopic geochemistry. We investigate one tholeiitic diorite, one TTG, two sanukitoids, one IAT gabbro and one WPT granite. Combining these geochronological and geochemical tools, we suggest the following evolution: an early moderately juvenile Siderian (ca. $2445 \mathrm{Ma}$ to $2300 \mathrm{Ma}$ ) arcrelated magmatism represented by the low-K diorite $(\varepsilon \mathrm{Nd}(\mathrm{t})$ of $-0.1 ;{ }^{87} \mathrm{Sr} /{ }^{86} \mathrm{Sr}(\mathrm{i}): 0.701 ; \varepsilon \mathrm{Hf}(\mathrm{t})$ from -8 to +3$)$, followed by moderately juvenile to evolved Rhyacian (ca. 2200-2182 Ma) arc-related magmatism characterized by coeval TTG-sanukitoid pulse $\left(\varepsilon N d(t)\right.$ from -0.6 to $-4.8 ;{ }^{87} \mathrm{Sr} /{ }^{86} \mathrm{Sr}(\mathrm{i})$ : $0.705 ; \varepsilon \mathrm{Hf}(\mathrm{t})$ from -11.7 to +2.5 ) and eventually by moderately juvenile (ca. 2130 Ma) IAT magmatism $\left(\varepsilon N d(t)=-0.05 ;{ }^{87} \mathrm{Sr} /{ }^{86} \mathrm{Sr}(\mathrm{i}): 0.702\right)$. A ca. $2035 \mathrm{Ga}$ collisional granulite event recorded in metamorphic rims and neoformed zircon grains with fir-tree textures ${ }^{[3]}$, possibly marks the amalgamation of the JFC onto another Paleoproterozoic basement unit of the Southern São Francisco Craton (Mantiqueira Complex). After collision and cratonization, a Statherian (ca. $1.78 \mathrm{Ga}$ ) episode of intra-plate magmatism was detected in the JFC by the WPT granitic pulse $(\varepsilon \mathrm{Nd}(\mathrm{t})$ : -8.1 ; $\varepsilon H f(t)$ from -13.9 to -5.7$)$. The integrated information provides preliminary petrogenetic insights for these magmatic episodes, such as melting of enriched source (Siderian tholeiitic diorite), interaction between mantle sources and supracrustal subducted material (sanukitoid suite), melting of the oceanic slab (TTG suite), and crustal assimilation (IAT Rhyacian gabbro and WPT Statherian granite).

1-Heilbron et al., (2017) Regional Geology Reviews, Springer. 2- Heilbron et al., (1997) Revista Brasileira de Geociências 27, 83-98. 